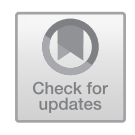

\title{
Analyzing Toru Dutt's Oeuvre Today: How a Transnational Literary-Educational Case from Colonial India Can Enrich Our Conception of Transnational History
}

\author{
Barnita Bagchi
}

This chapter looks back, from the vantage point of our contemporary globalization, to an earlier time of globalization, imperialism, and colonialism in South Asia and specifically India. In this context, we note at the outset that the India this chapter refers to is not present-day India, but India as it was in the later nineteenth century, which would include multiple present-day sovereign countries in South Asia, notably India, Pakistan, and Bangladesh. The case this chapter will discuss is that of Toru Dutt (1856-1877), one of the earliest Indian writers in English and French, whose short life spanned informal educational trajectories in India, France, and England. The chapter argues that we might enrich our conceptualization of the transnational in educational history in a number of ways by examining the educational trajectory, oeuvre, and friendships

B. Bagchi $(\square)$

Comparative Literature Section, Department of Languages, Literature, and Communication, Utrecht University, Utrecht, The Netherlands e-mail: B.Bagchi@uu.nl

(C) The Author(s) 2019

E. Fuchs and E. Roldán Vera (eds.), The Transnational in the History

of Education, Global Histories of Education, https://doi.org/10.1007/978-3-030-17168-1_7 
of Dutt as a young, highly educated female writer from colonial India. Conceptualization of the transnational is firmly rooted in my own standpoint and location as a transnational, cosmopolitan feminist scholar.

Toru Dutt's life took place within multicentric histories and trajectories, in which India under British colonialism, England, and France were key loci and influences. This chapter analyzes transnational history of education, playing out between the local and global spheres, of Dutt's life as writer-in-the-making, as captured in her letters and her bestknown biography by Harihar Das. ${ }^{1}$ A teenage prodigy who produced an astonishingly varied and rich corpus of literary works, in a life that spanned India and Europe, before dying at the age of twenty-one, Dutt created a transnational literary and cultural space for her work, in which female transnational friendships were key. I will argue in this chapter that a feminist perspective can lead us to recognize the enriching quality of such transnational female friendships and networks. Further, I will make the case for situating Dutt within the concepts of imperial as well as critical and vernacular cosmopolitanism and for regarding cosmopolitanisms in their various forms as significant elements in our conceptualization of the transnational. The chapter will progress to taking a brief look at key works in Dutt's fictional oeuvre to the end of illustrating how the content of that writing can enrich and enhance our conceptualization of the transnational in cultural and educational history. Finally, it will attempt to create bridges between educational trajectories of Dutt's time and those found in contemporary India. I argue that once one delves into the transnationalism and cosmopolitanism of a writer such as Dutt and of writers working in one's own time, it becomes vividly evident how very path-dependent such histories are, in the late nineteenth century as now: The legacies of British colonialism, entangled with the impact of the present-day inequalities of globalization, often continue to set templates for educational destinations for Indians and for choices they make around the languages they learn and write in. And yet, as the chapter will show, Dutt and her descendants have created transnational, critically cosmopolitan literature.

Fuchs and Roldán Vera have argued that understanding the transnational entails going beyond etymological precision or historical anecdotes on the origin of terms; instead, they assert, what is needed is an

${ }^{1}$ Harihar Das, Life and Letters of Toru Dutt (London: H. Milford, 1921). 
understanding of the interplay between "social reality," the concepts used by subjects and their contemporaries to make it intelligible (or to construct it), and the accumulation, displacement, and progressive density of meanings acquired by these concepts over time. ${ }^{2}$ True to this process, this chapter will set out to explore this interplay in the case of Dutt.

I am myself a transnational subject, affiliated to both the Netherlands and India, with educational and academic ties to the UK, and making regular use of three European and two Indian languages. As a feminist academic, much of whose research has been devoted to understanding women writers and women educators from India and Britain from 1780 to contemporary times, I am conscious of the influence upon the work in this chapter of my own scholarly and moral-political commitment to women's self-expression and agency across nation-states (or nation-states in the making).

Dutt was part of an era of imperial globalization. Fuchs has argued that, in the context of the longue durée, processes of globalization require fresh research perspectives ${ }^{3}$ which progress beyond the nation-state as a spatial and conceptual category. Undivided India, as colonized by the British in the nineteenth century, presents particularly compelling problems in this regard. Reinvented as a subordinated unit within the British Empire in 1857 , under the rule of Victoria, the inhabitants of nineteenth-century India claimed a diverse range of affiliations, including such to specific regions and, from the end of the century onward, to emergent notions of "nation." With India still to become a formal nation-state, and yet acutely aware of powerful established and emergent European nation-states ranging from Britain to France, Germany, and Italy, many educated Indians of the time imagined and thought between and across nations. Scholars such as Elleke Boehmer have argued that we today need to understand again what many of us have forgotten: the full reach of globalization under different varieties of European imperialism by the year 1900, with people traveling and migrating on a huge scale. Boehmer writes:

\footnotetext{
${ }^{2}$ Eckhardt Fuchs and Eugenia Roldan Vera, "The Concept of the Transnational" (Paper, Workshop on the Concept of the Transnational in Educational History, University of Istanbul, June 23, 2015).

${ }^{3}$ Eckhardt Fuchs, "History of Education: Beyond the Nation?" in Connecting Histories of Education Transnational and Cross-Cultural Exchanges in (Post)Colonial Education, ed. Barnita Bagchi, Eckhardt Fuchs, and Kate Rousmaniere (New York: Berghahn, 2014), $11-26$.
} 
[I]t was around one hundred years ago that Empire reached its widest, most 'globalised' extent ever. From the latter part of the nineteenth century until 1914 imperial trade was free and unfettered as never before, and as never since, until the mid-1990s. One hundred years ago, thousands of African males in the southern African subcontinent, and indentured Asians worldwide, both Indians and Chinese, had already become what we now call migrant workers, and were directly and indirectly implicated as such in imperial relations. (In all likelihood they did not however feel globalised, much as migrant workers and asylum seekers today have little reason for feeling so.) By 1900, just over one hundred years ago, with the laying of the cross-Pacific cable between Australia and Canada, the imperial communications network in fact went global. This cable was the farthest extension of a web that had begun to weave itself from the 1850s, with the overhead telegraph cabling of London, and the laying of several trans-Atlantic cables in the 1860s. In 1864 Bombay and London had been linked, the first instance of a cable being a lasting success, and from 1868 the Caribbean was woven into the wider network. ${ }^{4}$

Living in such a time of globalization fueled by imperialism, and traveling between India and Europe, Dutt thus appears as part of the web of interconnections and circulatory communicative and cultural energies of this globalization. She is also part of the analytical narrative that scholars, of which I am one, have been constructing in recent years around colonial women's education in the nineteenth century. In 2014, the present author, Fuchs, and Rousmaniere wrote:

The different transnational and transcultural interactions that mark the history of women's education in colonial sites include the recasting and questioning of gendered roles; conflicts around, and reinventions of, tradition and modernity; the creation of unusual registers, idioms and styles of articulation and writing; and highly creative transcultural exchanges. As noted in the literary texts of women writers, the particularly ambiguous, contradictory attributes of gender relations under colonialism allowed for [the] creation of certain moments of agency and autonomy. ${ }^{5}$

${ }^{4}$ Elleke Boehmer, "Global and Textual Webs in an Age of Transnational Capitalism; or, What Isn't New about Empire," Postcolonial Studies 7, no. 1 (2004): 11-26, accessed March 31, 2017, https://doi.org/10.1080/1368879042000210586.

${ }^{5}$ Barnita Bagchi, Eckhardt Fuchs, and Kate Rousmaniere, "Introduction," in Connecting Histories of Education: Transnational and Cross-Cultural Exchanges in (Post)Colonial Education, ed. Barnita Bagchi, Eckhardt Fuchs, and Kate Rousmaniere (New York: Berghahn, 2014), 5-6. 
Toru Dutt is an important figure exemplifying this analytical narrative. Her life allowed her to experience some of the privileges of education, in a space where access to modern "Western" education was variable and obeyed specific hierarchies. With class, caste, religion, and gender all impacting people's ability to access and participate in education in the colonial period, we have in Dutt a young Bengali Christian girl of the upper middle classes, whose parents schooled their children at home, which meant in India, but also, temporarily, England and France. Arguably, then, Dutt had parents who made their home encompass and expand out into the globalized world. Dutt's life and writing bear vivid traces of informal and lifelong learning, which so often characterized the education of women and other subaltern groups in colonial India. The late Meera Kosambi (1939-2015), a distinguished sociologist, who contributed wonderfully to transnational women's and educational history ${ }^{6}$ and to whom I pay special tribute in this chapter, taught us to take the transnational dimensions of Indian women writers' work seriously, even if she did not theorize these issues. I position myself squarely in this transnational (as well as transcultural) turn of literary and cultural studies and of the history of education. Such histories analyze relationships, dialogs, and interactions among different categories of educational actors and systems in India/South Asia and the counterparts of these actors and systems in other parts of the globe, with careful attention to differentiating and hierarchizing factors, two of the most significant being gender and colonialism. However, there is little work to date in the field of women's writing and education from colonial India/South Asia that explicitly conceptualizes the transnational. This chapter is an endeavor to fill that lacuna.

\section{Toru Dutt's Educational Histories}

Toru Dutt was the third and youngest child of Govin Chunder Dutt and Kshetramoni Dutt. Govin converted to Christianity in 1862, together with his wife and children; Toru was six years old at this point.

\footnotetext{
${ }^{6}$ See, for example, Meera Kosambi, “Women's Education through Women's Eyes: Literary Articulations in Colonial Western India," in Connecting Histories of Education: Transnational and Cross-Cultural Exchanges in (Post)Colonial Education, ed. Barnita Bagchi, Eckhardt Fuchs, and Kate Rousmaniere (New York: Berghahn, 2014), 193-212.
} 
Her mother Kshetramoni, though she eventually embraced Christianity actively, remained resistant to the new religion for some time and always remained steeped in Hindu mythology and vernacular, alongside Bengali cultural topoi including oral literature. Kshetramoni's skills in cultural mediation between India and Europe, Christianity and Hinduism, and Bengali and English appear to have been of a high order. According to her daughter's biographer, she translated at least one Christian tract from English into Bengali. ${ }^{7}$ It was Kshetramoni who imparted to her children a love of the tales of the Hindu epics, notably the Ramayana. A philanthropist, she left, after her death in 1900, a handsome legacy toward the construction of the Oxford Mission Church at Barisal in Bengal. Govin was employed in a fairly senior capacity in the British colonial civil service in Calcutta for some years; after finding that opportunities for advancement were limited, he devoted his life to learning, religion, and literature. His books included contributions to the remarkable family anthology of original poetry that he co-wrote with brothers and a cousin, The Dutt Family Album. ${ }^{8}$ Girish-or Greece-Chunder Dutt, Toru Dutt's uncle, taught his wife French and German, and the couple enjoyed reading authors such as Schiller together. Strong elements of the transnational were therefore already present in Toru Dutt's childhood, in the shape of the family's affiliation to Christianity, the father's love of writing in English, and a paternal side of the family that learnt and loved European languages other than English. From her mother's side, she learned Bengali and drew a love of Hindu myths, legends, and epics, which she complemented by learning Sanskrit in the last years of her life.

Toru Dutt and her siblings were primarily taught at home by their parents and by tutors, whether in Calcutta or during their long travels in Europe. The few brief exceptions occurred during Dutt's European sojourn. Apart from their home in Rambagan in the center of Calcutta, the Dutts had a beautiful garden-house in Bagmari, which Dutt spelt Baugmaree according to contemporary colonial convention; much of their learning and recreation took place there. Toru and her siblings Aru and Abju received instruction from a tutor, Shib Chunder Banerjee (who, for example, stimulated a great love of Milton's Paradise Lost in

\footnotetext{
${ }^{7}$ Das, Life and Letters of Toru Dutt, 7.

${ }^{8}$ Govin C. Dutt, The Dutt Family Album (London: Longman, Greens and Co., 1870).
} 
them), and a European singing teacher, Mrs. Sinaes. The family traveled to Europe after the death of Abju Dutt. The first Bengali women to visit Europe, Toru and her sister Aru learnt French at a school and privately during a four-month stay in Nice; they cultivated this basic knowledge assiduously after their departure and became great Francophiles, publishing, after their return to India, a collection of translations of French poetry into English, A Sheaf Gleaned in French Fields. ${ }^{9}$ France and its culture undoubtedly contributed greatly to the transnational quality of Dutt's mind. France also allowed Dutt to escape the prospect of imperial Britain being her only or principal transnational influence. Dutt's biographer Das observed:

England at that date had little to offer to young travelers from foreign countries, and the Higher Education of Women had hardly begun. It was perhaps a period in which the insularity of Britain was most marked. We are not surprised to read that France, the France of the Second Empire, had much more to teach the Dutt sisters and left deeper and more fruitful impressions on their minds. ${ }^{10}$

Dutt became a fervent supporter of the French nation and was anguished over France's defeat in the Franco-German War of 1870-1871. However, war was not her main preoccupation. Das cites numerous excerpts from letters by Dutt from France and England, which show that plays, literature, books, museums, and conversations with British men and women all kept Dutt and her sister busy during their stays in France and England. During the family's time in Cambridge, a visitor, who met them when Dutt was sixteen and her older sister was eighteen, was impressed by "their excellent command of English and especially by their wide knowledge of European life and thought." 11 In Cambridge, Toru attended Higher Lectures for Women, including lectures on French held by Lucien Boquel which benefited her a great deal, as did further private lessons in French.

\footnotetext{
${ }^{9}$ Toru Dutt and Aru Dutt, A Sheaf Gleaned in French Fields (Bhowanipore, Calcutta: Saptahik Sambad Press, 1876).

${ }^{10}$ Das, Life and Letters of Toru Dutt, 21.

${ }^{11}$ Ibid., 39.
} 
Aru Dutt also died after the Dutts' return to India. With the shadow of death darkening round the family, Dutt continued to read, write, and learn. She took up the study of Sanskrit in these years and produced her most mature literary works, including original poetry in English. She continued to read, speak, and write letters in Bengali, but did not choose that medium for creative writing. Toru's father remained her most constant teacher, and he wrote thus about his witty, learned daughter:

Not the least remarkable trait of Toru's mind was her wonderful memory. She could repeat almost every piece she translated by heart, and whenever there was a hitch, it was only necessary to repeat a line of the translation, to put an end to it, and draw out of her lips the whole original poem in its entireness. I have already said, she read much: she read rapidly too, but she never slurred over a difficulty when she was reading. Dictionaries, lexicons, and encyclopedias of all kinds were consulted until it was solved, and a note taken afterwards; the consequence was that explanations of hard words and phrases imprinted themselves, as it were, in her brain, and whenever we had a dispute about the signification of any expression or sentence in Sanskrit, or French, or German, in seven or eight cases out of ten, she would prove to be right. Sometimes 1 was so sure of my ground, that I would say, 'Well, let us lay a wager.' The wager was ordinarily a rupee. But when the authorities were consulted, she was almost always the winner. It was curious and very pleasant for me to watch her when she lost. First a bright smile, then thin fingers patting my grizzled check, then perhaps some quotation from Mrs. Barrett Browning, her favourite poetess, like this: 'Ah, my gossip, you are older, and more learned, and a man,' or some similar pleasantry. ${ }^{12}$

Govin, who clearly did not mind being beaten by his daughter, points to the influence on Toru Dutt of other women writers, across national boundaries. That Elizabeth Barrett Browning (1806-1861) was Dutt's "favourite poetess" also tells us something about Dutt's emergent sensibility. Barrett Browning had been a great admirer of Mary Wollstonecraft's late-Enlightenment feminism, and in Aurora Leigh, her nine-book epic, she poetically delineated the struggles of the protagonist Aurora to become a professional woman poet. ${ }^{13}$ Who knows, if Dutt had not died so

\footnotetext{
${ }^{12}$ Ibid., 24.

${ }^{13}$ Elizabeth Barrett Browning, Aurora Leigh (London: J. Miller, 1856).
} 
early she might have gone on to record the story of awakening of a transnational writer with Indian origins. In Dutt's own literary, cultural, and personal life, transnational female friendships with an English and a French woman played an intellectually and affectively enabling role.

\section{Dutt's Female Friendships and the Concept of the Transnational}

In 1872, when the Dutts were living in Cambridge, Toru Dutt met and became friends with Mary Martin, the only child of Reverend John Martin, a Fellow of Sidney Sussex College and vicar of Saint Andrew the Great in the city. The friendship became equally defining for Mary Martin. Through her contact with Dutt, Martin became interested in the missionary work of the Church of England in countries such as India, and, incidentally, visited Calcutta in 1910 and 1913, after Dutt's death. Once Dutt had returned to India from England, an epistolary correspondence replaced the long walks and conversations that she and Martin had enjoyed in Cambridge. In one letter, Mary Martin reproved Dutt for calling her fellow Indians "natives," in accordance with the racialized idiom of the British imperialists tended to do; Dutt acknowledged her mistake: "Thank you very much for what you say about calling my countrymen 'natives'; the reproof is just, and I stand corrected. I shall take care and not call them natives again. It is indeed a term only used by prejudiced Anglo-Indians, and I am really ashamed to have used it." 14 Dutt's side of this transnational conversation pointed to a rising anger in her about the inequitable and racially discriminatory governance of India by the British colonial power:

You are indignant at the way some Anglo-Indians speak of India and her inhabitants. What would you think if you read some of the Police reports which appear in the Indian daily papers? I shall tell you of a case which I read some months ago, and which impressed me then very much. I do not remember the details, but I shall tell you all that I can remember about it. Several soldiers went out for a holiday, having their guns with them. In a village they chanced to spy some peacocks, and they began shooting at them. The birds were the property of a Bengali farmer; of course

${ }^{14}$ Letter dated March 13, 1876, in: Das, Life and Letters of Toru Dutt, 131-132. 
he protested... From words they came to blows; one soldier was severely beaten; the others decamped, leaving nine Bengalis dead and some seven Bengalis wounded. The case was brought before the magistrate; and what do you think his judgement was? The villagers were fined each and all; the soldiers acquitted: 'natives should know how precious is the life of one British soldier in the eyes of the British Government.' ${ }^{\prime 5}$

One can infer that this was a friendship that did not articulate itself in the idiom of dominant colonizer (speaking for the cause of British colonialism and imperialism) and submissive colonized (accepting the concept, and praising the putative practice, of ethical colonialism or imperialism); rather, both parties looked at the India-Britain relationship with clear, critical eyes. When we discuss the transnationalism fostered by the British Empire, and varieties of the cosmopolitan, this insight into the nature of Dutt's female friendships is crucial in our theoretical framing.

Another mutually valued friendship of Dutt's was that with Clarisse Bader (1840-1902), a member of the French bourgeoisie who had, like Dutt, been educated at home. Bader knew French, Italian, English, and German and could translate Latin and Greek. A monarchist and Catholic, she was also an Indianist and an active member of the Asiatic Society of Paris, as well as being a patron of the Anti-Slavery Society of France. A historian and journalist, Bader also provided for her family, her father having lost his job. Dutt wrote to Bader requesting permission to translate the latter's book La femme dans l'Inde antique. ${ }^{16}$ Dutt, who was independently learning Sanskrit at the time, planned to use Bader's book as one of her reference points for choosing literature in Sanskrit to translate into English. Bader's book presents us with many stock topoi of contemporary scholarship about India, including an image of women of the time of the Vedas (the most ancient texts of Hinduism) as being noble, spiritual, self-abnegating, and tender. ${ }^{17}$ Dutt's conception of India thus drew not solely on her own vernacular

\footnotetext{
${ }^{15}$ Letter dated June 26, 1876, in: Das, Life and Letters of Toru Dutt, 168-169.

${ }^{16}$ Clarisse Bader, La femme dans l'Inde antique: Etudes, morales, et littéraires (Paris: Didier, 1867).

${ }^{17}$ Geeti Sen, Feminine Fables: Imaging the Indian Woman in Painting, Photography, and Cinema (Ahmedabad: Mapin Publishing, 2002), 60.
} 
knowledge, transmitted through her mother, nor only on the Sanskrit sources which she was beginning to access as she learnt the language, but, also, transnationally, on the history of women in India as written by the European woman Bader, whom we might today describe as a conservative feminist.

\section{Dutt's Fiction in the Context of the Transnational as a Concept in Educational History}

Toru Dutt was a translator, critic, anthologist, and novelist, in English and in French. She was the youngest among many Indian women writing in English in the period 1860 to 1920, such as Krupabai and Kamala Satthianadhan. Many of these authors were not Hindus, which was the religion of the majority in undivided British India; this is perhaps one reason why English was an appropriate choice of medium for many of these writers, who were at a remove not just from the British colonizers by virtue of race and subordinate position, but also from the Hindu majority, who were increasingly writing in vernacular Indian languages from the latter part of the nineteenth century in tandem with and in reference to a growing nationalism. Christian writers such as Dutt were less nationalistic and more transnational.

Dutt was one of the writers who helped articulate and constitute a form of cultural modernity in which the alternative domain of truth seen to be purveyed by the novel, a particularly influential nineteenth-century form of fiction, was crucial, and popular among women writers and readers, who were claiming greater participation and recognition in the public sphere and in the construction of knowledge. Early Indian novels by writers such as Dutt frequently revolve around imaginings of selves and subjects, often mediated via female protagonists. The novels argue for reform, both social reform and reform of the self, with racism and patriarchy targeted for critique; without education there can be no reform, and education thus figures importantly in Dutt's fiction, with its referentiality to the wider, multifaceted debate around the reform of gender relations and other matters in contemporary Indian society. In Dutt's novels, however, the Indian context can only be read obliquely and transnationally; one in English and one in French, they are both set in Europe. Accordingly, in reading Dutt I pursue a transnational reading of reform and especially of the reform of gender roles. 
Dutt lived to see only one of her works published: This was $A$ Sheaf Gleaned in French Fields, ${ }^{18}$ comprising translations of French poetry by her and her elder sister Aru. Edmund Gosse gave the volume a favorable review in The Examiner of August 26, 1876. Dutt's collection of original poetry (including poetic retellings of Hindu legends originally found in Sanskrit and Bengali), Ancient Ballads and Legends of Hindustan, was published posthumously in $1882,{ }^{19}$ with an introduction by Edmund Gosse. Dutt's French novel Le Journal de Mademoiselle D'Arvers was published in Paris in 1879; Clarisse Bader contributed a preface on the author's life and work. The book's front matter describes Dutt as a "jeune et célèbre Hindoue de Calcutta, morte en 1877," 20 which reads oddly today, as Dutt was not Hindu by religion. This appears to represent a categorization on the part of the publisher that would accommodate Dutt's Indianness in a way understandable to French readers at a time when it was not habitual to speak of inhabitants of India as "indien(ne)," which in turn is reflective of the contemporary lack of a nationstate named India.

Dutt's father Govin published her unfinished English-language novel Bianca, or the Young Spanish Maiden posthumously in the January-April 1878 issue of Bengal Magazine. ${ }^{21}$ Melancholy, death, and tragedy brood over Bianca throughout its incomplete pages. The eponymous protagonist is a young, half-Spanish, half-British woman, recently bereaved of her sister Inez and living in English exile with her Spanish father. This is a story of sensitivity and sensibility, with a jealous, over-possessive father who resents his surviving daughter being courted by the English aristocrat Lord Moore. In the delicate, sensitive, intelligent Bianca, steeped in French poetry and very much an outsider in England, we find many traces of Dutt herself. The half-Spanish Bianca becomes a representation, at transnational distance, of Indian heroines who likewise find themselves at a degree of remove from class-bound white British values which engenders the potential of these values' critique. When Bianca nearly dies after an illness, her father agrees to consent to her engagement with

\footnotetext{
${ }^{18}$ Toru Dutt and Aru Dutt, A Sheaf Gleaned in French Fields.

${ }^{19}$ Toru Dutt, Ancient Ballads and Legends of Hindustan (London: Kegan Paul, 1882).

${ }^{20}$ Toru Dutt, Le Journal de Mademoiselle D'Arvers (Paris: Didier, 1879).

${ }^{21}$ Toru Dutt, "Bianca, or, the Young Spanish Maiden," Bengal Magazine 6 (1878): 264-381.
} 
Lord Moore. Lord Moore's mother, however, calls Bianca a "wild girl"22 and "as proud as if she were the Queen of Spain." 23 The critical light thus shed upon British snobbery and xenophobia will appear in the further course of this chapter as an important strand in my argument that we need to read Dutt as a transnational, critically cosmopolitan writer.

Dutt's French-language Gothic novel Le Journal de Mademoiselle d'Arvers similarly takes a dominant tone of melancholy, tragedy, madness, and death, interwoven with a story of romantic love. N Kamala has argued that Dutt needed a language as distanced as was French from both English and Bengali, Dutt's obvious languages of affiliation, in order to generate narratives of romantic, sexual, and affective awakening. ${ }^{24}$ Dutt's use of French becomes a powerful exemplar of the transnational at work. Placing her plots in European contexts also allowed Toru to make use of the conventions of sensibility and the Gothic with which she was familiar from her reading of European novels. In this way, she created, using the European aesthetic modes of the Gothic and the novel of sensibility, an improvisational transnational literary space in which entrapped and victimized heroines, villainous, patriarchal male figures, spaces of tradition and threat such as dungeons and castles, and a highly affective and embodied register come together.

Marguerite, the heroine of Dutt's French novel, bears a strong resemblance to Toru Dutt herself, in physical description, sensitivity, and intelligence. Marguerite suffers by falling in love with Dunois, who is engaged in a rivalry with his brother for the affections of a serving-maid. When the two brothers eventually kill each other, Marguerite accepts the hand of the loving Louis. In Dunois and his brother, who are patriarchal and cruel to both Marguerite and the serving-maid, Dutt articulates a critique of unacceptable, power-based male predatory practices toward young, innocent women. By contrast, in the happy union of Louis and Marguerite, she proposes an alternative of a reformed conjugal contract characterized by greater equity between the sexes. It is a pattern similar to that observable in Bianca's critique of the protagonist's father and Lord Moore's mother, both faces of repressive, snobbish patriarchy, and

${ }^{22}$ Toru Dutt, Collected Prose and Poetry, ed. and intro. Chandani Lokugé (Delhi: Oxford University Press, 2006), 114.

23 Ibid.

${ }^{24}$ N. Kamala, "Toru Dutt: Ecrivaine francophile et francophone," Synergies Inde 4 (2009): 109, accessed March 31, 2017, https://gerflint.fr/Base/Inde4/kamala.pdf. 
in the validation of the mutual love connecting Lord Moore and Bianca. Both novels, in an eerie refracted mirroring of Dutt's and her siblings' early demise, contain premonitions of death. In Le Journal, Marguerite feels the presentiment of death through a dream of her husband, ${ }^{25}$ while in Bianca, Lord Moore goes away to fight in the Crimean War, with readers not knowing whether he will survive. Both novels vindicate the refinement, intelligence, and educated sensitivity of young women journeying through the school of life.

\section{Hyphenating the Cosmopolitan and the Transnational: Analytical Conclusions from the Case of Toru Dutt}

In recent years, we have returned to using the category of cosmopolitanism, simultaneously a rich, fuzzy, connotative concept and even more normative in nature than most variants of concepts of the transnational. Having outlined Dutt's life and work, I wish now to argue that we might usefully encapsulate both of these by hyphenating the cosmopolitan and transnational. The "cosmopolitan," as a word, brings together the notions of the cosmos, a wide universe, and the inhabitant of the polis, a space of citizenship. We might most helpfully, then, conceive of cosmopolitanism as a process in which narrow, facile affiliations to a particular nation, ethnicity, tribe, or class are found inadequate, and in which the cosmopolitan subject to some degree chooses his or her affiliations. The Stoics of ancient Greece were the first to formulate the idea of the cosmopolitan; what is arguably one of its most influential uses was by Immanuel Kant during the Enlightenment, in the context of world politics, when he advanced the idea of a federation of nations that would transcend purely national, selfish interests in the cause of global justice. ${ }^{26}$ Recent scholars, such as Kwame Anthony Appiah and Martha Nussbaum, have written about the notion of the cosmopolitan from a liberal, left-leaning point of view. ${ }^{27}$ Nussbaum has influentially directed a

${ }^{25}$ Dutt, Le Journal, 226.

${ }^{26}$ Immanuel Kant, "Idea for a Universal History with a Cosmopolitan Purpose," in Political Writings, ed. Hans S. Reiss (Cambridge: Cambridge University Press, 1991), 41-53; Immanuel Kant, Perpetual Peace (New York: Cosmo Books, 2005).

${ }^{27}$ Kwame Anthony Appiah, Cosmopolitanism: Ethics in a World of Strangers (New York: W. W. Norton, 2007); Martha Nussbaum, "Patriotism and Cosmopolitanism," Boston Review 19, no. 5 (1994), accessed March 31, 2017, http://bostonreview.net/BR19.5/nussbaum.html. 
spotlight on the potential of strands of cosmopolitanism to counter jingoism and shrill patriotism, pointing to the literary oeuvre of Rabindranath Tagore, born five years after Toru Dutt, as a fine example of cosmopolitan imagination. Scholars such as James Clifford and Bruce Robbins, who are critical of liberal philosophy, have also argued that a grounded, nuanced concept of the cosmopolitan remains fruitful. ${ }^{28}$

For my part, I find the explication and espousal of vernacular cosmopolitanism by the anthropologist Pnina Werbner to be helpful, as well as persuasive in moving us beyond a simplistically Eurocentric and elitist view of the cosmopolitan; Werbner has also undertaken much research on the vernacular cosmopolitanism of women. ${ }^{29}$ Joyce Goodman has recently presented a generative discussion of how feminist scholarship in the field of history of education might make conceptual use of the cosmopolitan. Goodman advocates a feminist notion of the cosmopolitan which acknowledges particularities, provides a space for transversal dialog, yet does not claim to produce final agreement among feminist scholars deploying the term "cosmopolitan." ${ }^{30}$ In this version of the cosmopolitan, to which I am happy to affiliate myself, recognition of the intersectionality of categories such as gender, race, colonial position, sexuality, and disability is key. We might term this "critical cosmopolitanism," in recognition of its engagement in a critique of simplistic and dominant categories, often aligned with power, such as exclusionary nationalism. In the context of Toru Dutt, we may also use the term "vernacular cosmopolitanism," which, as Werbner argues, is "an oxymoron that joins contradictory notions of local specificity and universal enlightenment." 31 Dutt engaged in a creative re-appropriation of the resources offered to her by imperial Britain, "writing back," as it were, via a poetics of proto-feminist agency and hybrid registers combining

${ }^{28}$ James Clifford, "Traveling Cultures," in Cultural Studies, ed. Lawrence Grossberg, Cary Nelson, and Paula Treichler (London: Routledge, 1992), 96-112; Bruce Robbins, “Comparative Cosmopolitanism," Social Text 31-32 (1992): 169-186.

${ }^{29}$ Pnina Werbner, "Vernacular Cosmopolitanism," Theory, Culture and Society 23, nos. 2-3 (2006): 496-498; Pnina Werbner, Anthropology and the New Cosmopolitanism: Rooted, Feminist and Vernacular Perspectives (New York: Berg, 2008).

${ }^{30}$ Joyce Goodman, "Gender, Cosmopolitanism, and Transnational Space and Time: Kasuya Yoshi and Girls' Secondary Education," History of Education 44, no. 6 (2015): 683-699, accessed March 31, 2017, https://doi.org/10.1080/0046760x.2015.1076066. As well as Goodman's article in this volume.

${ }^{31}$ Werbner, "Vernacular Cosmopolitanism," 496. 
French, English, Bengali, and Sanskrit resources. She also vernacularized the transnational literary space in her poetry, prose, and correspondence, operating for the major part of her life from a relatively marginal position in Calcutta, and fusing European and Bengali/Sanskrit/South Asian cultural elements and forms.

The perspective from which I, as a feminist transnational scholar critical of many aspects of today's inequitable neoliberal globalization, set out to analyze Toru Dutt's educational trajectories and work differs in its theoretical framing from that employed by earlier influential readers of her work who were directly connected with the British Empire. H.A.L. Fisher, a historian, British Liberal politician, and educator, was President of the Board of Education in David Lloyd George's coalition government (1916-1922) at the time of writing his foreword to Das's biography of Dutt (1921). Fisher commences it thus:

The subject of this volume is an Indian girl who, dying at the age of twenty-one, has left behind her a legacy in verse and prose which, quite apart from its true and delicate poetic quality, constitutes an amazing feat of precocious literary craftmanship. Toru Dutt was a poet with a rare genius for the acquisition of languages not her own. In her all too brief life she mastered Sanskrit and wrote in French and English with a grace, a facility, and an individual distinction which have given her rank among the authentic voices of Western literature. Her ear, indeed, sometimes betrayed her. On points of diction she was not always beyond reproach. Here and there in the Ancient Ballads and Legends of Hindustan or in her amazing renderings from the French poets, we come across a word, a phrase, a discord, which remind us that the poet was not of our race or speech, and much the same has been said of her French prose romance by those best qualified to judge of it. Yet when every deduction has been made for unessential blemishes, this child of the green valley of the Ganges has by sheer force of native genius earned for herself the right to be enrolled in the great fellowship of English poets. ${ }^{32}$

Capturing as he does Dutt's multilingual versatility, with its capacity to cut across spaces, affiliations, and nations, Fisher may appear to us as an early conceptualizer of both the transnational and the cosmopolitan in Dutt's literary oeuvre. But Fisher also shows his ideological limits: While graciously elevating Toru's work to the status of part of

${ }^{32}$ Das, Life and Letters of Toru Dutt, vii. 
"Western literature," he points out her linguistic infelicities, moments of "discord," as indicators that her "race" and "speech" are not "ours." Indeed, in an act of simultaneous othering and adoption, he deems the "child of $[\ldots]$ the Ganges" to earn her inclusion in the company of "English poets" by virtue of "native genius." And yet he does place her within this illustrious "fellowship." I would assert here that a certain imperial cosmopolitanism has facilitated Fisher's ability to include a writer from another race in the canon of English poets. In this age and (trans)locality, an individual did not count primarily as citizen of a nation, but rather as part of a larger and wider entity, which, to the distaste of many of us today, was simultaneously an empire. Notwithstanding its underlying, deeply embedded inequities and inequalities, notably those of race and ethnicity, empire employed a discourse of cosmopolitanism, and operated, of course, across nations, transnationally. Equally, as I have argued elsewhere, the colonial period saw the harnessing and reinvention of imperial transnationalism and cosmopolitanism by numerous Indian women writers and actors to the end of articulating subversive identities and positions and initiating an educational movement for women. ${ }^{33}$

Let us go on to the concluding paragraph of Fisher's foreword:

[...] Yet it is characteristic that all this tropical loveliness never completely contents or confines her. Home, after all, is in part exile. She cannot forget the beloved West, the enchantments of frost and snow, the delicate landscapes of France, the vivid, eager College life at Cambridge. In comparison with the stir and bustle of the West, the days in India seemed monotonous and without event. So in the midst of the profuse splendours of the East her thoughts continually reach out to that other home beyond the Ocean, which travel and study had made so dear to her, as, for example, to the world (known only through books) of the Brontë sisters, living among the lonely wild moors of Yorkshire, all three so full of talent, yet living so solitary amid those Yorkshire wolds, or to the days which stood out with such cameo-like distinctness in her memory, when she enjoyed the free life of a student by the banks of the Cam, passing 'nice cosy evenings' with her friend, and on Sundays drinking deep draughts of music from the College

${ }^{33}$ Barnita Bagchi, “Towards Ladyland: Rokeya Sakhawat Hossain and the Movement for Women's Education in Bengal, c. 1900-c. 1932," Paedagogica Historica 45, no. 2 (2009): 743-755, accessed March 31, 2017, https://doi.org/10.1080/00309230903335652. 
organ. In the long history of the contact and interfusion of East and West, I doubt whether there is a figure more encouraging or significant. ${ }^{34}$

Fisher's conceptual vocabulary thinks in terms of East and West. He can perceive only one part of the blurring, in Dutt's life, of boundaries between home and exile. Yet the other part is existent: Just as Toru missed England when she was not there, so also she longed for the other home in India when she was in Europe. In her transnational identities and the response to her work, she lived across and between nations and cultures, with a sense both of home and of exile wherever she was.

Toru Dutt's descendants in equivalent social positions, that is, the upper middle classes of today's India, would be highly unlikely to be home-schooled. Today, an aspiring writer in English from India has the advantage of a multi-channeled communicative publishing universe, far easier to access, in which the Internet and the digital "empire" facilitate communication and publication. When considering places and institutions outside South Asia to which a latter-day Toru Dutt might go to acquire informal or formal education, the USA, the UK, Australia, New Zealand, and Canada spring immediately to mind. ${ }^{35}$ The UK and its former white settler colonies head that list; the ongoing path-dependence of Indians in formal higher education on British colonialism is very evident. In terms of non-Indian languages that such a great-granddaughter of Toru might learn, English, German, and French remain popular choices (although Chinese in particular is increasingly sought after).

This path-dependence on the colonial does not preclude writers, then and now, from adopting ways of writing, communicating, forging friendships, and creating cultural spaces that in turn give birth to surprising, unusual narratives of gendered reform, female agency and voice, and the forging of a critical and vernacular cosmopolitan idiom. Dutt's creation of outsider-heroines in her transnational novels, her fine translations of French poetry, her transnational female friendships foregrounding women as critical cultural and political critics: These elements of her life and work, among others, acted as road maps for more recent writing by later, postcolonial, highly educated Indian women. The transnational

\footnotetext{
${ }^{34}$ Das, Life and Letters of Toru Dutt, viii.

${ }^{35}$ Yojana Sharma, "Surge in Growth of Indian Students Studying Abroad," University World News 416, June 1, 2016, accessed March 31, 2017, http://www.universityworldnews.com/article.php?story $=20160601180527213$.
} 
idiom of the half-German, half-Indian writer Anita Desai (1937-) and her Booker Prize-winning daughter Kiran Desai (1971-) come especially to mind here, and there is much data available for future work on how studying such recent transnational-cosmopolitan writers could enrich and modify the concept of the transnational in educational history.

In its heyday as an earlier variant of globalization, integrating "peripheral" and "central" lands into an unequal political and economic system, the British Empire furthered both exploitation and inequality; our current era of globalization also advances the inequitable exploitation of various world regions. But both in that era and in our own, while colonialism, empire, and the unequal progress of globalization have helped shape educational trajectories and writerly choices, they did not, and do not now, foreclose a critical spirit, surprising recombinations, and innovations that we may fruitfully analyze under the conceptual umbrella of the transnational in history.

\section{Bibliography}

Appiah, Kwame Anthony. Cosmopolitanism: Ethics in a World of Strangers. New York: W. W. Norton, 2007.

Bader, Clarisse. La femme dans l'Inde antique: Etudes, morales, et littéraires. Paris: Didier, 1867.

Bagchi, Barnita. "Towards Ladyland: Rokeya Sakhawat Hossain and the Movement for Women's Education in Bengal, c. 1900-c. 1932." Paedagogica Historica 45, no. 2 (2009): 743-755. Accessed March 31, 2017. https://doi. org/10.1080/00309230903335652.

Bagchi, Barnita, Eckhardt Fuchs, and Kate Rousmaniere. "Introduction." In Connecting Histories of Education: Transnational and Cross-Cultural Exchanges in (Post)Colonial Education, edited by Barnita Bagchi, Eckhardt Fuchs, and Kate Rousmaniere, 1-8. New York: Berghahn, 2014.

Boehmer, Elleke. "Global and Textual Webs in an Age of Transnational Capitalism; or, What Isn't New about Empire.” Postcolonial Studies 7, no. 1 (2004): 11-26. Accessed March 31, 2017. https://doi.org/10.1080/13688 79042000210586.

Browning, Elizabeth Barrett. Aurora Leigh. London: J. Miller, 1856.

Clifford, James. "Traveling Cultures." In Cultural Studies, edited by Lawrence Grossberg, Cary Nelson, and Paula Treichler, 96-112. London: Routledge, 1992.

Das, Harihar. Life and Letters of Toru Dutt. With a preface by H. A. L. Fisher. London: H. Milford, 1921. 
Dutt, Govin C. The Dutt Family Album. London: Longman, Greens and Co, 1870 .

Dutt, Toru. Ancient Ballads and Legends of Hindustan. London: Kegan Paul, 1882 .

Dutt, Toru. "Bianca, or, the Young Spanish Maiden." Bengal Magazine 6 (1878): 264-381.

Dutt, Toru. Collected Prose and Poetry. Edited and with an introduction by Chandani Lokugé. Delhi: Oxford University Press, 2006.

Dutt, Toru. Le Journal de Mademoiselle D'Arvers. Paris: Didier, 1879.

Dutt, Toru, and Aru Dutt. A Sheaf Gleaned in French Fields. Bhowanipore, Calcutta: Saptahik Sambad Press, 1876.

Fuchs, Eckhardt. "History of Education Beyond the Nation? Trends in Historical and Educational Scholarship." In Connecting Histories of Education: Transnational and Cross-Cultural Exchanges in (Post)Colonial Education, edited by Barnita Bagchi, Eckhardt Fuchs, and Kate Rousmaniere, 11-26. New York: Berghahn, 2014.

Fuchs, Eckhardt, and Eugenia Roldán Vera. "The Concept of the Transnational." Paper presented at the International Workshop on the Concept of the Transnational in Educational History, University of Istanbul, June 23, 2015.

Goodman, Joyce. "Gender, Cosmopolitanism, and Transnational Space and Time: Kasuya Yoshi and Girls' Secondary Education." History of Education 44, no. 6 (2015): 683-699. Accessed March 31, 2017. https://doi.org/10.1 080/0046760x.2015.1076066.

Kamala, N. "Toru Dutt: Ecrivaine francophile et francophone." Synergies Inde 4 (2009): 101-111. Accessed March 31, 2017. https://gerflint.fr/Base/ Inde4/kamala.pdf.

Kant, Immanuel. "Idea for a Universal History with a Cosmopolitan Purpose." In Political Writings, edited by Hans S. Reiss, translated by H. B. Nisbet, 41-53. Cambridge: Cambridge University Press, 1991. Originally published in 1784 .

Kant, Immanuel. Perpetual Peace. New York: Cosmo Books, 2005. Originally published in 1795.

Kosambi, Meera. “Women's Education through Women's Eyes: Literary Articulations in Colonial Western India." In Connecting Histories of Education: Transnational and Cross-Cultural Exchanges in (Post)Colonial Education, edited by Barnita Bagchi, Eckhardt Fuchs, and Kate Rousmaniere, 193-212. New York: Berghahn, 2014.

Nussbaum, Martha. "Patriotism and Cosmopolitanism." Boston Review 19, no. 5 (1994). Accessed March 31, 2017. http://bostonreview.net/BR19.5/nussbaum.html.

Robbins, Bruce. “Comparative Cosmopolitanism." Social Text 31-32 (1992): 169-186. 
Sen, Geeti. Feminine Fables: Imaging the Indian Woman in Painting, Photography, and Cinema. Ahmedabad: Mapin Publishing, 2002.

Sharma, Yojana. "Surge in Growth of Indian Students Studying Abroad." University World News 416, June 1, 2016. Accessed March 31, 2017. http://www.universityworldnews.com/article.php?story $=20160601180527213$.

Werbner, Pnina. Anthropology and the New Cosmopolitanism: Rooted, Feminist and Vernacular Perspectives. New York: Berg, 2008.

Werbner, Pnina. "Vernacular Cosmopolitanism." Theory, Culture and Society 23, nos. 2-3 (2006): 496-498. 